\title{
Initial decay of woody fragments in soil is influenced by size, vertical position, nitrogen availability and soil origin
}

\author{
Annemieke van der Wal • Wietse de Boer • \\ Wiecher Smant • Johannes A. van Veen
}

Received: 9 July 2007 / Accepted: 21 September 2007 / Published online: 12 October 2007

(C) Springer Science + Business Media B.V. 2007

\begin{abstract}
Fast-growing bacteria and fungi are expected to cause the initial stage of decomposition of woody fragments in and on soils, i.e. the respiration of sugars, organic acids, pectin and easily accessible cellulose and hemi-cellulose. However, little is known about the factors regulating initial wood decomposition. We examined the effect of wood fragment size, vertical position, nitrogen addition and soil origin on initial wood decay and on the relative importance of fungi and bacteria therein. Two fractions of birch wood were used in microcosm experiments, namely wood blocks (dimensions: $3 \times 0.5 \times 0.5 \mathrm{~cm}$ ) and sawdust (dimensions: 0.5-2 mm). The woody fragments were enclosed in nylon bags and placed on top of- or buried in an abandoned arable soil and in a heathland soil. After 15, 25 and 40 weeks of incubation, fungal biomass was quantified (as ergosterol and chitin content) and
\end{abstract}

Responsible Editor: Barbara Wick.

A. van der Wal

Laboratory for Ecological Risk Assessment,

National Institute for Public Health and the Environment,

Antonie van Leeuwenhoeklaan 9,

3720 BA Bilthoven, The Netherlands

A. van der Wal $(\bowtie) \cdot$ W. de Boer $\cdot$ W. Smant

J. A. van Veen

Netherlands Institute of Ecology (NIOO-KNAW),

Centre for Terrestrial Ecology,

Boterhoeksestraat 48,

6666 GA Heteren, The Netherlands

e-mail: annemieke.van.der.wal@rivm.nl bacterial numbers were determined. The results indicated that initial wood decay was mostly caused by fungi; bacteria were only contributing in sawdust in/on abandoned arable soil. Larger fragment size, burial of fragments and nitrogen addition positively influenced fungal biomass and activity. Fungal biomass and decay activities were much lower in woody fragments incubated in/on heathland soil than in those incubated in/on abandoned arable soil, indicating that soil origin is also an important factor determining initial wood decay.

Keywords Bacteria $\cdot$ Decomposition $\cdot$ Fungi $\cdot$ Litter . Nitrogen $\cdot$ Particle size $\cdot$ Wood decay

\section{Introduction}

Wood is an important component of organic matter in ecosystems that are dominated by shrubs and trees, and is mainly composed of cellulose, hemicellulose and lignin (Schmidt 2006). During the initial stages of wood decomposition, bacteria and fast growing, opportunistic fungi can degrade simple soluble substrates, pectin and easily accessible cellulose and hemi-cellulose (De Boer et al. 2005; Van der Wal et al. 2006a). The degradation of these carbon sources does not require the production of lignindegrading enzymes. In later stages of decomposition, the ligno-cellulose matrix in wood is attacked by slow growing, saprotrophic, ligno-cellulolytic fungi. These 
fungi are able to degrade lignin using extra-cellular enzymes thereby getting access to cellulose and hemicellulose (Boddy and Watkinson 1995; Shah and Nerud 2002; De Boer et al. 2005). Until now, not much attention has been paid to factors regulating initial wood decomposition and the relative importance of bacteria and fungi therein.

Factors that influence the decomposing activity of fungi during wood decay are moisture content, oxygen concentration, acidity, temperature and nutrient concentrations, especially that of nitrogen (Nicholas and Crawford 2003). However, these factors have mostly been studied for the more advanced stages of wood decay (Daniel 2003; Schmidt 2006). Little is known about the factors that regulate the first stages of decomposition.

The effect of nitrogen additions on litter decomposition has been studied extensively and it is generally concluded that initial decomposition of litter is nitrogen-limited as $\mathrm{N}$ addition often results in higher mass loss or respiration (Fog 1988; Berg et al. 1998; Eiland et al. 2001; Moorhead and Sinsabaugh 2006). This is attributed to the relief of $\mathrm{N}$ limitation for fastgrowing fungi and bacteria (Fog 1988; Carreiro et al. 2000). However, some studies found no effect of $\mathrm{N}$ addition on decomposition (Prescott 1995; Hobbie and Vitousek 2000). Thus, results are not consistent and the mechanism of the effect of nitrogen on the initial decomposition rate is still not clarified. Differences in the relative importance of bacteria and fungi may contribute to the variation in decomposition response upon nitrogen addition. It is expected that bacteria will respond more to nitrogen addition than fungi, as the latter are thought to be more efficient in the use of nitrogen (re-allocation) (Griffin 1985). In addition to possible shifts in microbial community structure, microbial growth efficiency is expected to be affected by high levels of nitrogen. Previous studies suggested that high levels of nitrogen increase the growth yield efficiency of micro-organisms, i.e. per unit of utilized substrate $\mathrm{C}$ a greater proportion of biomass is produced than under nitrogen limited conditions, because less energy is then required for obtaining $\mathrm{N}$ (Blagodatskiy et al. 1993; Agren et al. 2001; Thiet et al. 2006). Wood and litter have low levels of nitrogen, and decay fungi have developed strategies to deal with this sub-optimal nitrogen concentration for growth. One of the strategies is the translocation of nitrogen via hyphae from soil to wood or litter (Frey et al. 2000).
Another potential factor affecting the rate of initial wood decomposition is the accessibility of the substrate. In a former study on constraints for fungal biomass development in abandoned arable fields, we showed that the biomass of opportunistic fungi was enhanced after mixing sawdust into abandoned arable soils (Van der Wal et al. 2006a). However, the small size of the woody particles may also have stimulated growth of bacteria as they have relatively easy access to degradable substrates. In addition, small woody particles exhibit a relatively large surface area to the surrounding soil, making close contact with soil nitrogen. This can provide a more favorable environment for bacterial growth relative to fungal growth (Holland and Coleman 1987). Larger sizes of woody fragments and placement on top of the soil, e.g. resembling a litter layer, are expected to favor filamentous fungi over bacteria since the substrates may be far more difficult to reach for unicellular soil organisms (Griffin 1985; Frey et al. 2000; Klein and Paschke 2004).

We hypothesized that 1) large wood particles, in particular when placed on top of the soil, will favor fungal decomposition, 2) nitrogen addition will increase initial wood decay since it relieves the nitrogen limitation for opportunistic wood-degrading micro-organisms, 3) nitrogen addition will positively influence the growth yield efficiency of fungi and 4) soil origin will influence the rate of initial wood decay via soil properties (e.g. pH) and composition of soilborne, wood-invading micro-organisms. To study this, we used two fractions of birch wood and two different soil origins, a recently abandoned arable soil and a heathland soil, in microcosm experiments. These soils were chosen to compare the fungal dynamics in a bacterial dominated soil with a relatively high $\mathrm{pH}$ (recently abandoned arable land) and a fungal dominated soil with a relatively low $\mathrm{pH}$ (heathland) (Van der Wal et al. 2006b). The effect of all treatments on development of bacterial numbers was taken into account to understand the fungal biomass dynamics.

\section{Materials and methods}

The experiment is set up as a case study. We used two different sizes of wood fragments, two different levels of nitrogen (addition of nitrogen versus no addition), 
two positions of wood placement (burial or on top of soil) and two different soil origins (abandoned arable land versus heathland). Hence, each treatment is tested in only two soils and these soils differ in many ways (e.g. soil properties, land use). The conclusion about the effect of soil origin on initial wood decay should therefore be considered with caution.

\section{Soil and sampling}

One abandoned arable field (abandoned since 2002), named Telefoonweg (about 4 ha), with a low fungal biomass and one heathland, named Mossel (about $4 \mathrm{ha}$ ), with a high fungal biomass, were selected from a previous study (Van der Wal et al. 2006b). The heathland soil is podzolic (Typic Haplorthod, according to the US soil taxonomy) developed in glacial sandy deposits and the abandoned arable soil has a disturbed profile (former heathland, Typic Haplorthod) due to agricultural activities. The soil characteristics of both fields are listed in Table 1. We collected randomly at least $80 \mathrm{~kg}$ of the upper $10 \mathrm{~cm}$ of mineral soil from a plot of $30 \times 30 \mathrm{~m}$. Since the upper $3 \mathrm{~cm}$ of the heathland soil consisted of organic matter, the 3$13 \mathrm{~cm}$ layer was collected. For each site, the soil was bulked, homogenized, sieved (4 $\mathrm{mm}$ mesh) and stored field moist at $4{ }^{\circ} \mathrm{C}$ for not more than 10 days until the start of the experiment.

\section{Experimental set-up and sample handling}

In order to determine the effect of substrate accessibility on initial wood decay, two fragment sizes of birch wood were used in the experiments namely birch wood blocks (dimensions: $3 \times 0.5 \times 0.5 \mathrm{~cm}$ ) and birch sawdust (dimensions: $0.5-2 \mathrm{~mm}$ ). To create a similar thickness of woody layers $(0.5 \mathrm{~cm})$, twice as much weight (10.0 $\mathrm{g}$ dry weight) of wood blocks than of wood sawdust (5.0 g dry weight) was enclosed in nylon bags $(7 \times 7 \mathrm{~cm}, 1 \mathrm{~mm}$ mesh size $)$, since the volume of sawdust was approximately twice as much as that of the blocks. Approximately $550 \mathrm{~g}$ of each soil was weighed into plastic boxes $(10 \times 10 \times$ $5 \mathrm{~cm}$ ). To examine the effects of burial on initial wood decay, the autoclaved wood-containing bags were either placed on top of the soil or buried in the soil (covered by a $3 \mathrm{~cm}$ layer of soil). Soil without wood addition served as control. Finally, we included the effect of $\mathrm{N}$ enrichment on initial wood decay. A $\mathrm{C}$ : $\mathrm{N}$ ratio of 20 was created by autoclaving the wood-containing bag followed by dripping carefully a $\left(\mathrm{NH}_{4}\right)_{2}\left(\mathrm{SO}_{4}\right)\left(0.35 \mathrm{~g}\right.$ to sawdust, $0.70 \mathrm{~g}\left(\mathrm{NH}_{4}\right)_{2}\left(\mathrm{SO}_{4}\right)$ to wood blocks) solution in water on the wood. The wood absorbed all added $\left(\mathrm{NH}_{4}\right)_{2}\left(\mathrm{SO}_{4}\right)$ solution. These samples are hereafter referred to as 'high N' samples, whereas samples that did not receive the $\left(\mathrm{NH}_{4}\right)_{2}\left(\mathrm{SO}_{4}\right)$ solutions are referred to as 'low N' samples. Total moisture content of woodblocks was adjusted to $80 \%$ $(\mathrm{w} / \mathrm{w})$ which is a normal value for moisture content in hardwood (Schmidt 2006). For sawdust fragments, having a higher surface/volume ratio, moisture content was adjusted to $150 \%$, which is in the range of the moisture content of the litter layer in the heathland. Soils were incubated at their respective field moisture content (at the day of sampling) which was $11.8 \%(\mathrm{w} / \mathrm{w})$ and $13.9 \%(\mathrm{w} / \mathrm{w})$ for the abandoned arable field and the heathland, respectively. Plastic boxes were closed with a perforated plastic lid. Soils were incubated at $20^{\circ} \mathrm{C}$ and boxes were weighed during incubation to adjust for any water loss if needed. Four replicate samples per treatment were separately analyzed after 15,25 and 40 weeks of incubation.

After each incubation period, saw dust and wood blocks were collected and the dry weight was determined. Both sawdust and woodblocks (after grounding in a mill) were analyzed for ergosterol, chitin, numbers of bacterial colony forming units, enzyme activities, mineral $\mathrm{N}$, total $\mathrm{C}$ and total $\mathrm{N}$. Soil adjacent to the wood bags $(0.5 \mathrm{~cm})$ was also collected. The rest of the soil (hereafter referred to as 'bulk' soil) was mixed per sample. Soil samples were analyzed for mineral $\mathrm{N}$ and fungal biomass. Before analysis, wood and soil samples were stored at $-20^{\circ} \mathrm{C}$.

Table 1 Soil characteristics of the mineral horizon; $0-10 \mathrm{~cm}$ for the abandoned arable field and $3-13 \mathrm{~cm}$ for the heathland site

\begin{tabular}{lllllll}
\hline Soil name & Land use & $\mathrm{pH}-\mathrm{H}_{2} \mathrm{O}$ & $\mathrm{C} \mathrm{g} \mathrm{kg}$ & $\mathrm{C}: \mathrm{N}$ ratio & Ergosterol content mg kg & $\mathrm{Soil}^{-1}$ texture \\
\hline Telefoonweg & Arable field abandoned in 2002 & 5.4 & 22.5 & 26.2 & 0.16 & Coarse sand \\
Mossel & Heathland & 3.9 & 40.8 & 35.1 & 0.25 & Coarse sand \\
\hline
\end{tabular}


Mass loss and fungal biomass dynamics

Mass loss of wood in the nylon bags was calculated as the difference in dry weight between fresh and incubated woody fragments and is expressed as a percentage of the original mass. Ergosterol, a sterol only found in fungal cell membranes (Weete 1989), was used as a fungal-specific biomarker and extraction from wood samples was conducted according to methodology of Bååth (2001) for soil samples. Wood $(0.25 \mathrm{~g})$ of each sample was added to $1 \mathrm{ml}$ cyclohexane and $4 \mathrm{ml} 10 \% \mathrm{KOH}$ in methanol. After $15 \mathrm{~min}$ ultrasonic treatment, the samples were heated at $70^{\circ} \mathrm{C}$ for $90 \mathrm{~min}$. Next, $1 \mathrm{ml}$ distilled water and $2 \mathrm{ml}$ cyclohexane was added to the tubes, which were then vortexed for $30 \mathrm{~s}$ and centrifuged. The top phase was removed and the remaining wood suspension was extracted again with $2 \mathrm{ml}$ cyclohexane and the combined cyclohexane fractions were evaporated under $\mathrm{N}_{2}$ at $40^{\circ} \mathrm{C}$. The precipitates were dissolved in methanol and then filtered over a $0.2 \mu \mathrm{m}$ filter. Samples were transferred to an auto-sampler for HPLC analysis. Ergosterol in soil samples was extracted according to Gong et al. (2001), since it has been shown to be as good as the more laborious Bååth method in samples with a low organic matter content (De Ridder-Duine et al. 2006). Fresh soil $(4 \mathrm{~g})$ was added to $6 \mathrm{ml}$ methanol together with $2 \mathrm{~g}$ $0.3-0.5 \mathrm{~mm}$ and $2 \mathrm{~g} 0.7-1 \mathrm{~mm}$ glass beads. After samples were shaken for $1 \mathrm{~h}$, the supernatant was centrifuged for $10 \mathrm{~min}$ at $11,000 \mathrm{rpm}$. The supernatant was then filtered over a $0.2 \mu \mathrm{m}$ filter and analyzed using HPLC. Ergosterol concentration $\left(\mathrm{mg} \mathrm{kg}^{-1}\right)$ was measured using a Dionex HPLC equipped with a $\mathrm{C}$ 18 reverse-phase column (De Ridder-Duine et al. 2006).

Chitin, an important structural component of the fungal cell wall, was measured by determining the hexosamine content of ground wood samples $(500 \mathrm{mg})$ after hydrolysis with $5 \mathrm{ml} 6 \mathrm{~N} \mathrm{HCl}\left(24 \mathrm{~h}\right.$ at $\left.100^{\circ} \mathrm{C}\right)$ (Eikenes et al. 2005). Hexosamine was measured colorimetrically using the method of Johnson (1971).

\section{Bacterial numbers}

Bacteria in wood samples were enumerated by plate counting as described by De Ridder-Duine et al. (2005) for soil samples. Wood samples $(0.5 \mathrm{~g})$ were transferred to polypropylene screw-cap tubes contain- ing $10 \mathrm{ml}$ of sterile phosphate buffer $\left(0.25 \mathrm{~g} \mathrm{l}^{-1}\right.$ $\mathrm{KH}_{2} \mathrm{PO}_{4}$ in de-mineralized water; adjusted to $\mathrm{pH} 6.5$ ). The tubes were shaken intensively on a bench top for $90 \mathrm{~min}$ at $20^{\circ} \mathrm{C}$, sonicated at $47 \mathrm{kHz}$ for $10 \mathrm{~min}$, and shaken for an other $30 \mathrm{~min}$. Ten-fold dilutions were made in phosphate buffer and $50 \mu$ of appropriate dilutions were plated on $1 / 10$ strength TSB agar (NaCl $5 \mathrm{~g} \mathrm{l}^{-1}, \mathrm{KH}_{2} \mathrm{PO}_{4} 1 \mathrm{~g} \mathrm{l}^{-1}, 3 \mathrm{~g} \mathrm{l}^{-1}$ Tryptic Soy Broth [Oxoid, Basingstoke, England] $1 \mathrm{~g} \mathrm{l}^{-1}$, agar $20 \mathrm{~g} \mathrm{l}^{-1}$; $\mathrm{pH}$ 6.5) Media contained $50 \mathrm{mg} \mathrm{l}^{-1}$ of the fungal inhibitor natamycin [Delvocid, DSM, Delft, NL]. Plates were incubated in the dark at $20^{\circ} \mathrm{C}$ for 2 weeks. During this period, plates were checked regularly for colony formation.

Enzyme assays

All enzyme activities were assayed in the same extracts. MilliQ water $(4 \mathrm{ml})$ was added to $1 \mathrm{~g}$ milled, fresh wood and shaken for $1 \mathrm{~h}$ at room temperature. Enzyme extracts were made by pressing the moistened, milled wood over an iron filter (pore size $2 \mathrm{~mm}$ dia). Filtrates were transferred to Eppendorf cups and after centrifuging for $10 \mathrm{~min}$ at $10,000 \mathrm{rev} \mathrm{m^{-1 }}$, the supernatants were frozen $\left(-20^{\circ} \mathrm{C}\right)$ until analysis of enzyme activity.

Laccase and manganese peroxidase activities were measured as indicators for lignin degradation (Leonowicz et al. 1999). Laccase activity was measured via oxidation of ABTS (2,2'-azinobis(3ethylbenzthiazoline-6-sulfonic acid)) according to Bourbonnais and Paice (1990). Manganese peroxidase activity was measured via the oxidative coupling of DMAB (3-dimethylaminobenzoic acid) and MBTH (3-methyl-2-benzothiazolinone hydrazone hydrochloride) in the presence of $\mathrm{Mn}^{2+}$ and $\mathrm{H}_{2} \mathrm{O}_{2}$, as described by Daniel et al. (1994).

Activity of endo-1,4- $\beta$-glucanase as an indicator of cellulase was estimated using carboxymethyl cellulose linked with Remazol brilliant blue R (Azo-CMCellulose, Megazyme, Bray, Ireland). The reaction mixture contained $200 \mu \mathrm{l}$ of $2 \%$ Azo-CM-Cellulose in MQ and $200 \mu$ l enzyme extract. Samples were incubated at $40^{\circ} \mathrm{C}$ for $30 \mathrm{~min}$ and the reaction was stopped by adding $1 \mathrm{ml}$ of precipitation solution (20\% sodium acetate trihydrate and $3 \%$ zinc acetate in $100 \mathrm{ml} \mathrm{MQ}$ ). The formation of blue dye was measured spectrophotometrically at $590 \mathrm{~nm}$. The conversion to activity was based on a calibration 
curve of Remazol brilliant blue (RBB) and expressed as mmol RBB/24 hours/gram dry weight. The activity of endo-1,4- $\beta$-xylanase (xylanase) as indicator of hemicellulase was estimated by a similar procedure using birchwood xylan linked with Remazol brilliant blue (Azo-xylan, Megazyme, Bray, Ireland) as a substrate.

\section{Analysis of nitrogen availability}

To determine the leaching of mineral $\mathrm{N}$ from the wood into the soil, mineral $\mathrm{N}$ of both portions of soil (adjacent soil and 'bulk' soil) was extracted by shaking $2 \mathrm{~g}$ soil (dry weight) in $10 \mathrm{ml} 1 \mathrm{M} \mathrm{KCl}$ for $1 \mathrm{~h}$. Mineral $\mathrm{N}$ in the wood was determined by shaking $0.5 \mathrm{~g}$ wood (dry weight) in $5 \mathrm{ml} 1 \mathrm{M} \mathrm{KCl}$ for $1 \mathrm{~h}$. Concentrations of $\mathrm{NH}_{4}^{+}-\mathrm{N}$ and $\mathrm{NO}_{3}^{-} \mathrm{N}$ in the $\mathrm{KCl}$ extract were determined colorimetrically using a Traacs 800 auto-analyzer. Total $\mathrm{C}$ and $\mathrm{N}$ of wood after the second and third incubation period were analyzed on a FlashEA 1112 Series NC soil analyzer.

\section{Statistical analyses}

All data were analyzed per soil origin using univariate regression within the general linear model (GLM) procedure in SPSS for Windows (Release 12.0.1; standard version) with $\mathrm{N}$ addition, vertical position of the wood-containing bag, wood fragment size and incubation time as factors. The assumption of normality was tested with Shapiro-Wilk statistics and homogeneity of variance was assessed with Levene's test. Differences between groups were tested with Tukey's honestly significant difference test or, when variances were unequal, with Tamhane's T2 test at $p<$ 0.05 .

To determine the amount of fungal biomass growing into the soil from the woody fragments, we first compared the amount of ergosterol content in control soil (without wood addition) with that of wood-containing bulk soil. The difference in ergosterol content between the control soil and the soil that was $>0.5 \mathrm{~cm}$ separated from the wood-containing bags turned out to be less than $4 \%$ in all treatments. Therefore, we assumed that the presence of woodcontaining bags did not increase the amount of fungal biomass in the bulk soil. The percentage of fungal biomass growing from wood into adjacent soil $(<0.5 \mathrm{~cm})$ was calculated as: (the concentration of ergosterol in adjacent soil-the concentration of ergosterol in 'bulk' soil)/concentration of ergosterol measured in wood)* $100 \%$.

The relation between fungal biomass (ergosterol or chitin content) and mass loss of wood was calculated by the coefficient of the linear equation at $p=0.05$. We defined the growth yield efficiency of fungi as the amount of fungal biomass produced per unit of substrate and calculated this as (ergosterol content/\% wood mass loss).

\section{Results}

Mass loss

Over the whole incubation period, strong differences in mass loss were observed between different treatments. The lowest decay (about 5\% mass loss) had occurred in $\mathrm{N}$-enriched sawdust that was buried in heathland soil, whereas the highest decay (about $47 \%$ mass loss) had occurred in N-enriched wood blocks buried in abandoned arable soil. In general, the mass loss of woody fragments was higher for the abandoned arable soil than for the heathland soil $(p<0.05$, Fig. 1). For the abandoned arable soil, mass loss of wood increased with incubation time for all treatments, except for wood blocks with low $\mathrm{N}$ placed on top of the soil ( $p>0.84$, Fig. 1). For the heathland soil, mass loss only increased with time in treatments with high $\mathrm{N}$, except for wood blocks placed on top of the soil ( $p>0.22$, Fig. 1). For both soils, mass loss of wood was, in general, higher in blocks than in sawdust. Over the whole incubation period, nitrogen addition increased mass loss of both wood blocks and sawdust in the abandoned arable field, however, for the heathland soil nitrogen addition did not have such an effect. Burial of the woody fragments had a significant positive effect on decay for the abandoned arable soil ( $p<0.05$, Fig. 1). The opposite was found for the heathland soil i.e. a higher decay of woody fragments that were incubated on top of the soil $(p<$ 0.05 , Fig. 1).

For the abandoned arable soil, fungal biomass (ergosterol) and mass loss correlated positively $\left(R^{2}=\right.$ $0.59, n=72, p<0.05$ ), except for wood blocks with low $\mathrm{N}$ placed on top of the soil and sawdust with high $\mathrm{N}$ buried in soil $\left(R^{2}=0.01, n=12, p>0.80\right.$ and $R^{2}=$ $0.14, n=12, p>0.23$ respectively). In the heathland, 
Fig. 1 Effect of nitrogen addition (high $\mathrm{N} /$ low $\mathrm{N}$ ) and vertical position (in soil/ on soil) on mean values of mass loss (error bars represent standard deviation) of sawdust and of wood blocks after 15, 25 and 40 weeks of incubation. a wood incubated in/on abandoned arable soil, b wood incubated in/on heathland soil
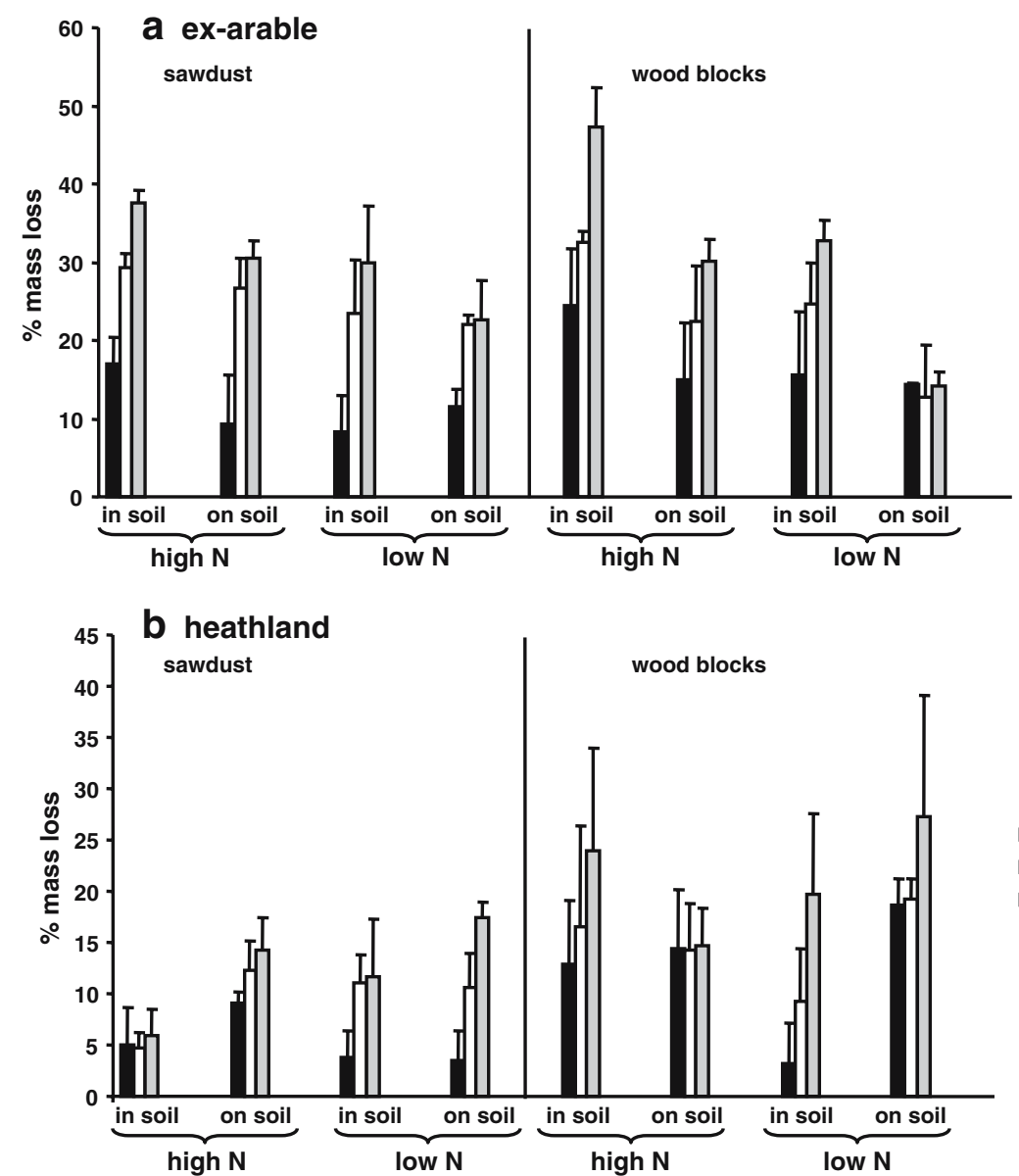

15 weeks $\square 25$ weeks 口40 weeks mass loss correlated significantly with ergosterol content in all treatments $\left(R^{2}=0.28, n=96, p<0.05\right)$.

Fungal biomass dynamics and bacterial numbers

Ergosterol and chitin, the two biomarkers that were used to follow fungal biomass dynamics during initial wood decay, were significantly correlated $\left(R^{2}=0.93\right.$, $n=64, p<0.05)$. Therefore, the results of only one of the biomarkers, ergosterol, will be presented. For both soils, ergosterol was, in general, higher in woodblocks than in sawdust $(p<0.05$, Fig. 2). Nitrogen addition had a positive effect on the ergosterol content for all treatments during the first incubation period. However, at later sampling times nitrogen addition did not affect fungal biomass (ergosterol), except for the woodblocks in/on abandoned arable soil $(p<0.05$, Fig. 2). In contrast, all wood samples without Nenrichment showed an increase of ergosterol with incubation time. The vertical position of the woody fragments also had an effect on ergosterol content: buried fragments had, in general, a higher ergosterol content than those incubated on top of the soils $(p<$ 0.05 , Fig. 2). There was a strong effect of soil origin on the amount of ergosterol: woody fragments incubated in/on heathland soil contained much less ergosterol than those incubated in/on abandoned arable soil.

For both soils and all treatments, exploratory growth of fungi that colonized the wood was limited as ergosterol concentration in soil adjacent to woody fragments was less than $0.3 \%$ of that in wood.

Fragment size, soil origin and nitrogen addition had strong effects on bacterial numbers (Table 2). For both soils, the numbers of bacteria in woodblocks were always lower than the detection limit $\left(8 * 10^{3}\right.$ CFU g ${ }^{-1}$ dry wood) of the method used. For the heathland soil, bacterial numbers were below the detection limit in most of the sawdust samples. Detectable, but low, numbers of bacteria were only 
Fig. 2 Effect of nitrogen addition (high N/ low N) and vertical position (in soil/ on soil) on mean values of ergosterol content $\left(\mathrm{mg} \mathrm{kg}^{-1}\right)$ (error bars represent standard deviation) in sawdust and in wood blocks after 15 , 25 and 40 weeks of incubation. a wood incubated in/ on abandoned arable soil, b wood incubated in/on heathland soil
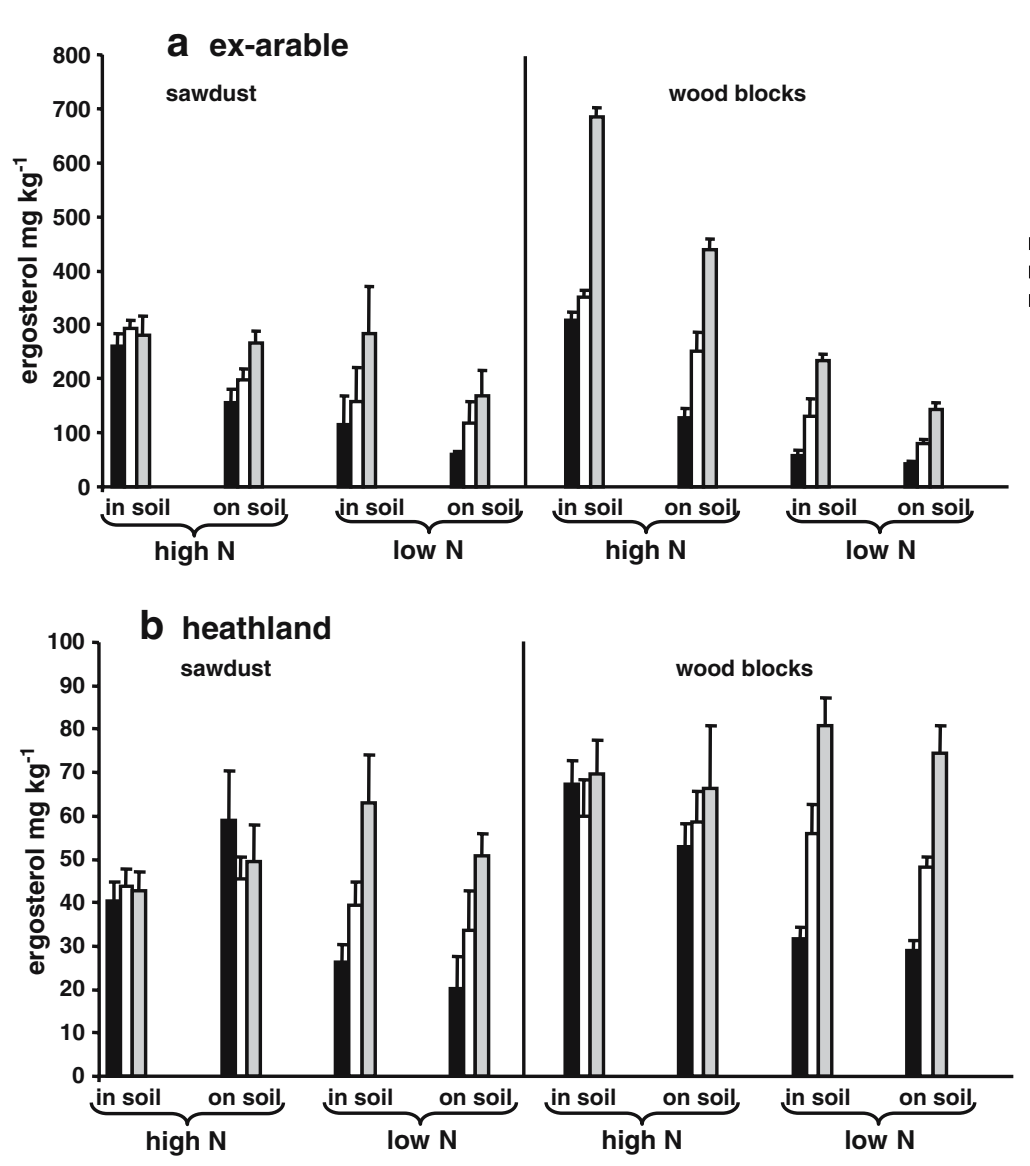

15 weeks 口 25 weeks 마 weeks found to be present at the first harvest in sawdust without nitrogen enrichment (Table 2). In contrast, high numbers of bacteria (up to $4 * 10^{8} \mathrm{CFU} \mathrm{g} \mathrm{g}^{-1}$ dry wood) were present in several sawdust samples that had been incubated in/on abandoned arable soil. For this soil a strong inhibiting effect of nitrogen addition on bacterial CFU was observed during the first harvest $(p<0.05$, Table 2). In fact, a similar effect

Table 2 Effect of nitrogen addition (high N/low N) and vertical position (in soil/on soil) on mean values of bacterial numbers ( $\mathrm{g}^{-1} \mathrm{dry}$ weight wood) (standard deviation in brackets) in sawdust after 15 and 40 weeks of incubation in the abandoned arable and heathland soil. Letters $\mathrm{A}$ and $\mathrm{B}$ denote differences at $P<0.05$ level between sawdust samples with high and low $\mathrm{N}$

\begin{tabular}{|c|c|c|c|c|c|c|c|}
\hline \multicolumn{4}{|l|}{ High N } & \multicolumn{4}{|l|}{ Low N } \\
\hline $\begin{array}{l}\text { In soil } \\
\text { after } \\
15 \text { weeks }\end{array}$ & $\begin{array}{l}\text { after } \\
40 \text { weeks }\end{array}$ & $\begin{array}{l}\text { On soil } \\
\text { after } \\
15 \text { weeks }\end{array}$ & $\begin{array}{l}\text { after } \\
40 \text { weeks }\end{array}$ & $\begin{array}{l}\text { In soil } \\
\text { after } \\
15 \text { weeks }\end{array}$ & $\begin{array}{l}\text { after } \\
40 \text { weeks }\end{array}$ & $\begin{array}{l}\text { On soil } \\
\text { after } \\
15 \text { weeks }\end{array}$ & $\begin{array}{l}\text { after } \\
40 \text { weeks }\end{array}$ \\
\hline \multicolumn{8}{|c|}{ Abandoned arable soil } \\
\hline $\begin{array}{l}3.60 \mathrm{E}+0.6 \\
(4.05 \mathrm{E}+0.6) \mathrm{A} \\
\text { Heathland soil }\end{array}$ & $\begin{array}{l}2.00 \mathrm{E}+0.8 \\
(9.13 \mathrm{E}+07)\end{array}$ & $\begin{array}{l}1.00 \mathrm{E}+0.6 \\
(9.52 \mathrm{E}+05) \mathrm{A}\end{array}$ & $\begin{array}{l}1.34 \mathrm{E}+0.8 \\
(8.77 \mathrm{E}+07)\end{array}$ & $\begin{array}{l}2.44 \mathrm{E}+0.8 \\
(8.30 \mathrm{E}+07) \mathrm{B}\end{array}$ & $\begin{array}{l}2.80 \mathrm{E}+0.8 \\
(6.43 \mathrm{E}+07)\end{array}$ & $\begin{array}{l}1.32 \mathrm{E}+0.8 \\
(6.18 \mathrm{E}+07) \mathrm{B}\end{array}$ & $\begin{array}{l}4.26 \mathrm{E}+0.8 \\
(6.35 \mathrm{E}+07)\end{array}$ \\
\hline$<8000 \mathrm{~A}$ & $<8000$ & $<8000 \mathrm{~A}$ & $<8000$ & $\begin{array}{l}1.78 \mathrm{E}+0.6 \\
(9.70 \mathrm{E}+05) \mathrm{B}\end{array}$ & $<8000$ & $\begin{array}{l}1.20 \mathrm{E}+0.6 \\
(1.35 \mathrm{E}+06) \mathrm{B}\end{array}$ & $<8000$ \\
\hline
\end{tabular}


was apparent for the heathland soil albeit that the numbers of bacteria in the non-nitrogen enriched sawdust samples were much lower than in the abandoned arable soil $(p<0.05$, Table 2$)$. The negative effect of nitrogen addition on bacterial numbers in sawdust in/on abandoned arable soil was still apparent at the last harvest. Yet, numbers of bacteria in the nitrogen treated samples were much higher than at the first harvest.

The presence of low numbers of bacteria in wood samples based on plate counts was confirmed by the inability to obtain PCR-amplified 16S RNA gene fragments from these samples (results not shown).

\section{Enzyme activities}

For all treatments and throughout the whole incubation period, both sawdust and woodblocks had very low activities of the enzymes laccase and manganese- peroxidase, indicating a low capacity of fungi for the degradation of lignin (data not shown).

In contrast to the low lignolytic enzyme activities, both cellulase and hemi-cellulase activities were clearly detectable. Differences between treatments became already apparent after the first incubation period when both cellulase and hemi-cellulase activities peaked. The (hemi-) cellulase activities in the woody fragments were lower for the heathland soil than for the abandoned arable soil ( $p<0.05$, Figs. 3 and 4$)$. Nitrogen addition had a strong positive effect on hemi-cellulase and cellulase activities in sawdust and woodblocks for both soils ( $p<0.05$, Figs. 3 and 4 ). In addition to nitrogen-enrichment, fragment size had also an effect on the (hemi-) cellulase activities: in the abandoned arable soil woodblocks had higher cellulase and hemi-cellulase activities than sawdust, whereas the reverse was observed for the heathland soil $(p<0.05$, Figs. 3 and 4). Burial of the woody fragments had a
Fig. 3 Effect of nitrogen addition (high $\mathrm{N} /$ low $\mathrm{N}$ ) and vertical position (in soil/ on soil) on mean values of hemicellulase (mmol Remazol brilliant blue (RBB) ${ }^{-1}$ $24 \mathrm{~h}^{-1}$ ) activity (error bars represent standard deviation) in sawdust and in wood blocks after 15, 25 and 40 weeks of incubation. a wood incubated in/on abandoned arable soil, b wood incubated in/on heathland soil

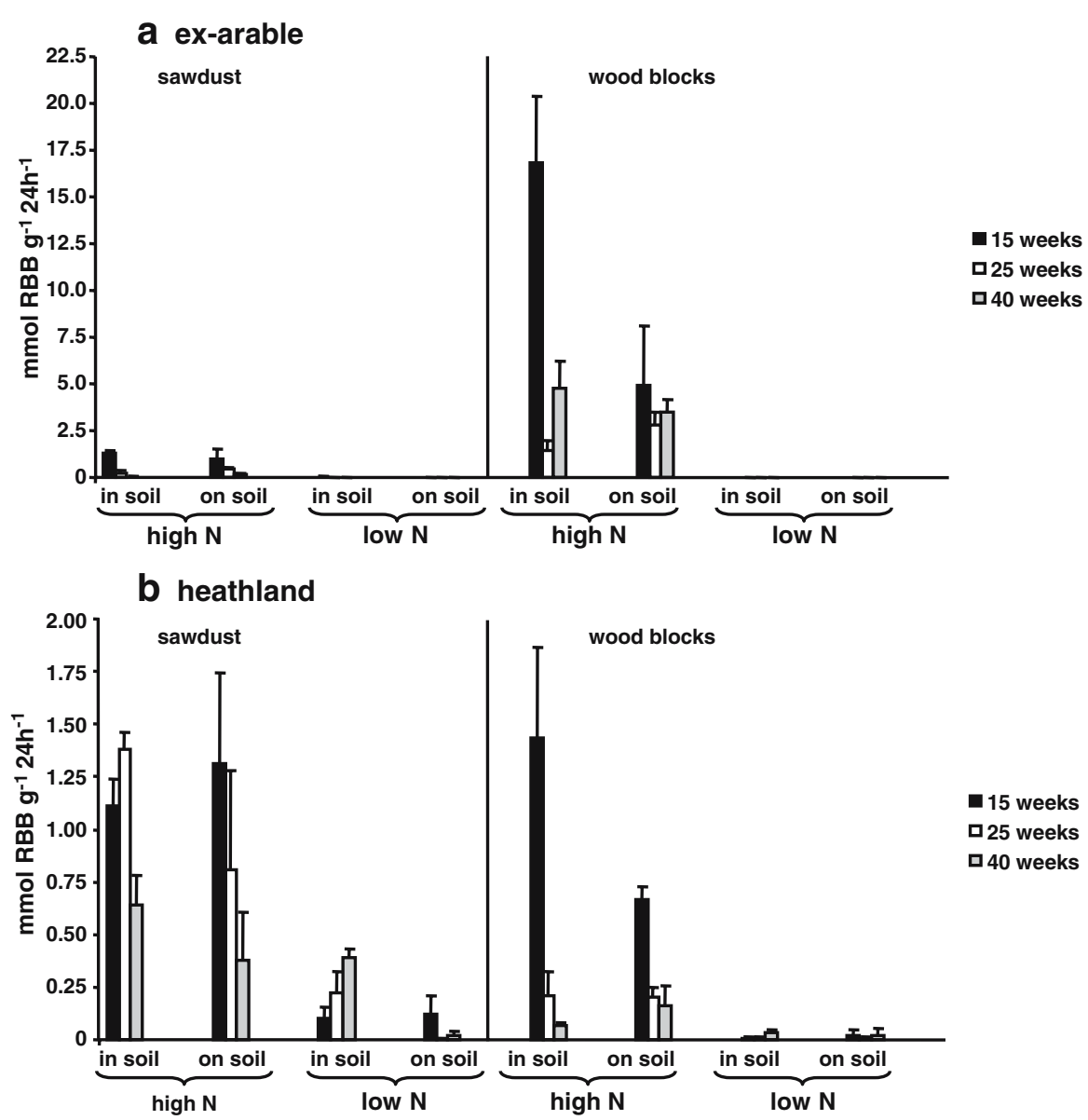


Fig. 4 Effect of nitrogen addition (high $\mathrm{N} /$ low $\mathrm{N}$ ) and vertical position (in soil/ on soil) on mean values of cellulase (mmol Remazol brilliant blue (RBB) $\mathrm{g}^{-1}$ $24 \mathrm{~h}^{-1}$ ) activity (error bars represent standard deviation) in sawdust and in wood blocks after 15, 25 and 40 weeks of incubation. a wood incubated in/on abandoned arable soil, b wood incubated in/on heathland soil

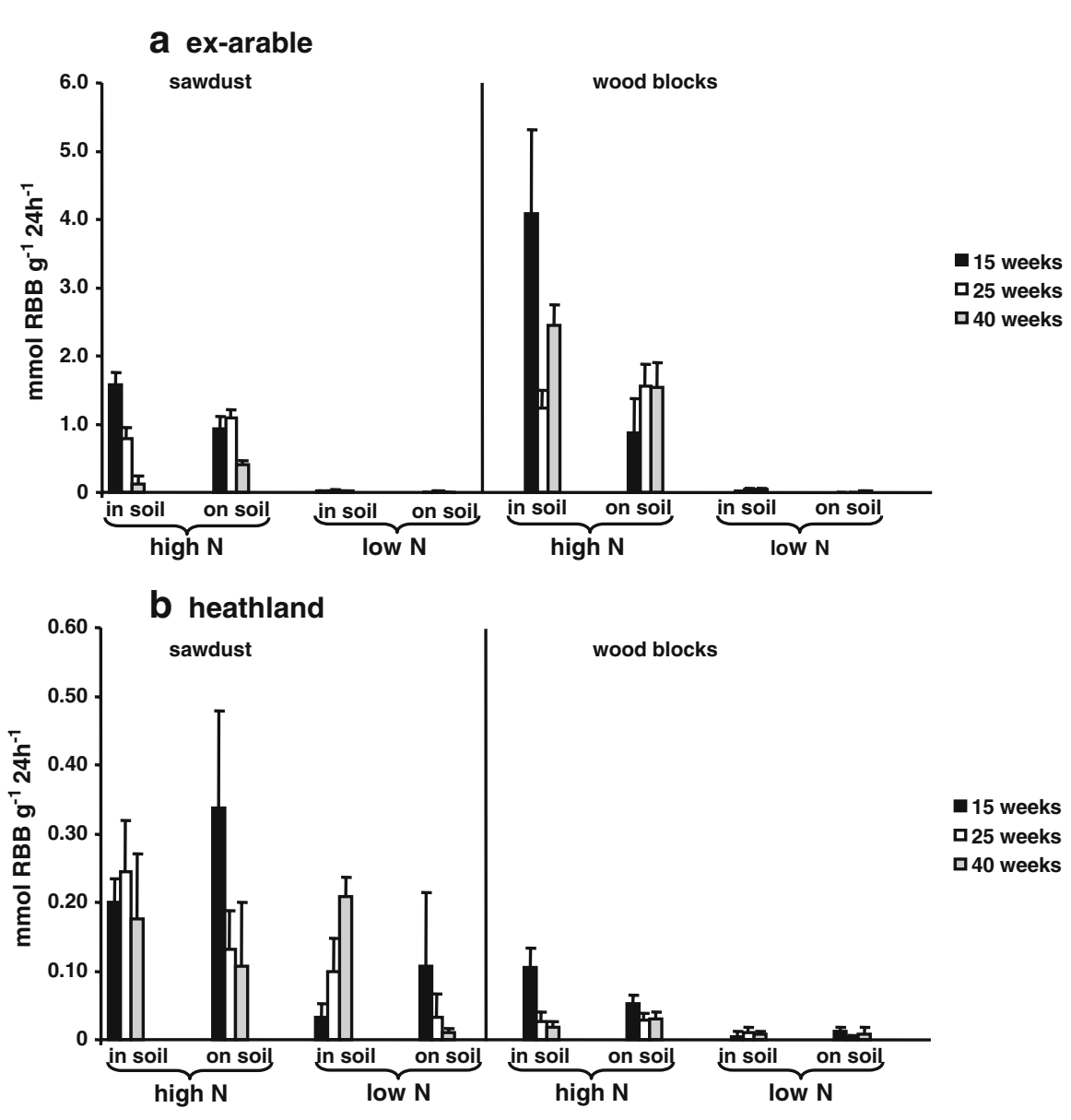

significant positive effect on hemi-cellulase and cellulase activities for both fields ( $p<0.05$, Figs. 3 and 4).

Fungal growth yield efficiency

For the abandoned arable soil, the fungal growth yield efficiency, the amount of fungal biomass produced per $\%$ mass loss (= indication of amount of utilized substrate), was higher in nitrogen-enriched wood than in untreated wood $(p<0.05$, ratio of $11.5 \pm 3.6$ versus $7.3 \pm 4.1)$. Burial of woody fragments had also a positive effect on growth yield efficiency $(p<0.05$, $10.2 \pm 4.6$ versus $8.5 \pm 4.0$ ). However, the size of the wood fragments did not influence the efficiency ( $p>$ 0.88). During incubation, the efficiency increased after the second harvest $(p<0.05$, from 9.9 to 10.2 to 9.9 again). For the heathland soil, the fungal growth yield efficiency showed no significant differences between treatments $(p>0.19)$.
Transfer of nitrogen between wood and soil

After the first incubation period, at least $90 \%$ of added mineral $\mathrm{N}$ had disappeared from the wood (both sawdust and woodblocks) and about $90 \%$ of this fraction could be recovered from both soils (mean of $2.2 \pm 0.4 \%$ in adjacent soil and $88.2 \pm 20.0 \%$ in 'bulk' soil).

For the abandoned arable soil, the increase in total $\mathrm{N}$ in wood after the second incubation period was $15.2 \pm 3.7 \mathrm{mg} \mathrm{N}$ per non-enriched sample and $34.3 \pm$ $12.4 \mathrm{mg} \mathrm{N}$ per nitrogen-enriched sample. The difference between these values is significant $(p<$ 0.05 ), indicating that nitrogen addition positively influenced the effect of nitrogen transfer to wood. After the third incubation period this difference was still significant. The increase in total $\mathrm{N}$ in wood after the second incubation period was $28.9 \pm 15.8 \mathrm{mg} \mathrm{N}$ per buried sample and $19.6 \pm 9.6 \mathrm{mg} \mathrm{N}$ per sample 
placed on top of the soil. The difference between these values is close to significance $(p=0.055)$. The difference between the treatments remained the same after the third incubation period. For the heathland soil, nitrogen addition did not influence the effect of nitrogen transfer to the wood $(p>0.30)$. The increase in total $\mathrm{N}$ in wood after the second incubation period was $13.4 \pm 4.2 \mathrm{mg} \mathrm{N}$ per buried sample and $7.9 \pm$ $8.7 \mathrm{mg} \mathrm{N}$ per sample placed on top of the soil. The difference between these values is significant $(p<0.05)$, but the effect of placement on nitrogen transfer disappeared after the third incubation period $(p>0.30)$.

\section{Discussion}

All factors that we have examined, i.e. soil origin, size of the woody fragments, their vertical position (in soil versus on top of soil) and nitrogen addition had an effect on fungal and bacterial dynamics and initial wood decomposition.

\section{Soil origin}

Wood decomposition (mass loss), cellulolytic enzyme activities, fungal biomass indicators (chitin and ergosterol) and bacterial numbers were much lower in woody fragments incubated in/on the heathland than in those incubated in/on the abandoned arable soil. This suggests that soil origin is influencing initial wood decay. The lower density and activity of fungi in woody fragments in/on heathland may be due to the inhibiting activity of polyphenolic materials diffusing into the woody fragments. Organic matter composed of remainders of Calluna vulgaris (heather) is rich in polyphenolic compounds that have been shown to be inhibitory to microbial processes (Jalal and Read 1983). Such inhibitory compounds may also explain the very low numbers of bacteria in woody fragments in/on the heathland soil. The lower $\mathrm{pH}$ of woody fragments in/on heathland soil as compared to that in/ on abandoned arable soil may also have affected growth and activity of wood-inhabiting microorganisms. However, this seems more likely for bacteria than for fungi as most fungi are well able to cope with low pH levels (Griffin 1985; Mulder et al. 2005). More information on the effect of soil origin on initial wood decay is needed and these results can provide a basis for additional research.
Size of the woody fragments

Both ergosterol and chitin determinations indicated that fungal biomass was higher in woodblocks than in sawdust. The decomposition rate (mass loss) of wood was also higher in woodblocks. For the abandoned arable soil, bacterial numbers in woodblocks were much lower than in sawdust. Opportunistic bacteria may be constrained to colonize woodblocks as they do not form hyphae to penetrate solids (Griffin 1985; Frey et al. 2000; Klein and Paschke 2004). Hence, for the abandoned arable soil a better fungal growth in woodblocks as compared to sawdust may be caused by a lower competitive pressure of bacteria. A negative effect of bacteria on fungal growth has been suggested to be due to bacterial release of lytic enzymes degrading fungal cell walls, to the production of antifungal compounds (antibiotics) or to the competition for available organic compounds between bacteria and fungi (De Boer et al. 2003; Romani et al. 2006). Since there is a lower decomposition rate in sawdust as compared to woodblocks, we assume that there are negative effects (antagonism) of bacteria on fungi and vice versa resulting in a net lower decomposition. For the heathland soil, a lower competitive pressure of bacteria in woodblocks as compared to sawdust is not likely as numbers of bacteria were below the detection limit in most cases for both woodblocks and sawdust. Here, differences in fungal biomass and activity between sawdust and woodblocks may be caused by a different rate of absorbance of inhibitory heatherderived polyphenolics.

Our observations for the abandoned arable soil appear to be in contrast with the findings of Griffith and Bardgett (2000) who found no differences in fungal activity in grass lamina fragment of different sizes. However, they used sterile pieces of grass and inoculated only isolated fungi. Therefore, in their study no other soil micro-organisms could negatively affect fungal colonization of smaller fragments. Thus, in a more natural environment the competitive pressure of bacteria against fungi in small-sized lignocellulose-rich materials may be substantial.

Vertical position of the woody fragments

For both soils, buried wood (sawdust and blocks) developed a higher fungal biomass and cellulase and hemi-cellulase activities than wood placed on top of 
the soil. These results, together with the undetectable or very low lignolytic enzyme activities, indicate that opportunistic, cellulolytic fungi were dominating the initial decomposition process and were, unexpectedly, favored by burial of the substrate. The positive effect of burial on fungal biomass and - activity was already apparent at the first harvest and appears not to be related to interactions with bacteria as the numbers of bacteria were not affected by burial at this stage. The positive effect of burial on fungal biomass and activity is in agreement with Osono et al. (2006) who found more fungal hyphae on needles placed beneath the litter layer than on needles on the litter surface. They ascribed this to the higher moisture content of the needles in the soil. In our study, the moisture content of woody fragments buried in soil was generally similar to those placed on top of soil. Therefore, a difference in moisture content between wood buried in soil and that on top of soil is not likely as an explanation for our results. We observed a positive effect of burial on transfer of nitrogen from soil to wood. This may suggest that fungi benefit from a better access to soil nitrogen.

Nitrogen addition

In general, addition of nitrogen to wood resulted in an increase of decomposition and of fungal biomass formation. However, this was a short-tem effect since after prolonged incubation (40 weeks), differences between ergosterol content in wood with and without $\mathrm{N}$ addition diminished in most cases. Interestingly, colonization of sawdust by bacteria was reduced by addition of nitrogen, but also this effect disappeared with time. This is probably due to the leaching of the added nitrogen (90\%) from the woody fragments to the soil during the first incubation period. Hence, nitrogen addition appeared to be more advantageous for opportunistic fungi than for bacteria. This is surprising as bacteria are expected to be more affected by $\mathrm{N}$ limitation than fungi (Griffin 1985). Degradation of purified cellulose is often stimulated by high levels of mineral N (Fog 1988; Carreiro et al. 2000; Sjöberg et al. 2004; Waldrop et al. 2004). Wood is composed of cellulose, hemi-cellulose and lignin. Part of the cellulose and hemi-cellulose is easily accessible and, therefore, the first increase of decomposition activity after addition of nitrogen is probably due to the stimulation of degradation of this fraction of the wood. This is also confirmed by the $\mathrm{N}$-induced increase of activity of (hemi-)cellulase after the first incubation period. Hence, it appears that the decay activities of the opportunistic fungi were nitrogen limited. The leveling-off of ergosterol concentrations and (hemi-)cellulase activity during subsequent incubation would then be explained by the complete utilization of all easily accessible (hemi-)cellulose, the leaching of added nitrogen from wood to soil, or by the immobilization of nitrogen into microbial biomass, resulting in renewed nitrogen limitation (Terziev and Nilsson 1999).

The amount of exploratory hyphae was very low in all treatments. We expected that $\mathrm{N}$ translocation would be most pronounced in untreated wood to overcome nitrogen deficiency (Scheu and Schauermann 1994). In the abandoned arable soil, this was not the case; nitrogen-enriched wood even increased the transfer of nitrogen from soil to wood. In all treatments, nitrogen in wood increased with time. Therefore, it appears that a low amount of exploratory hyphae is sufficient for efficient transport of nitrogen. The fact that nitrogen addition to wood even increased $\mathrm{N}$ translocation in abandoned arable soil may be due to the aforementioned leaching of the added $\mathrm{N}$ from woody fragments, making the uptake of mineral $\mathrm{N}$ from soil easy for fungi.

In the abandoned arable soil, the growth yield efficiency was higher after nitrogen addition which confirms previous studies (Blagodatskiy et al. 1993; Agren et al. 2001; Thiet et al. 2006). Possible explanations for this can be that the same fungi are just growing more efficiently, or that there is a shift in the fungal decomposer community towards fungi that are more efficient but have a greater nitrogen demand (Agren et al. 2001). However, in the heathland soil we could not detect such an increase in efficiency of fungi after nitrogen addition. This may point to a different fungal community composition in wood exposed to heathland soil. The inhibiting compounds present in the heathland soil may be more important for selection of fungi than nitrogen addition.

In most treatments, loss of wood mass was positively correlated with ergosterol content suggesting that fungi were responsible for the decomposition of wood. However, in nitrogen-enriched sawdust buried in abandoned arable soil we observed an increase in mass loss without an increase in fungal biomass. In the nitrogen-enriched sawdust in/on abandoned arable soil, bacterial numbers were rela- 
tively low at the first harvest and increased strongly during prolonged incubation. Hence, the lack of correlation between fungal biomass and mass loss may be due to an increase in bacterial decomposing activity during prolonged incubation.

The growth of rot fungi in wood was, even after 40 weeks of incubation, still very low as indicated by the low activity of lignin degrading enzymes. Therefore, the incubation time of this study appears to be too short for lignocellulolytic fungi to colonize the substrate or to produce lignin degrading enzymes. However, it is also possible that antagonistic, opportunistic fungi were hampering the colonization of rot fungi (Greaves 1972).

In this study, initial wood decomposition by bacteria appeared to be mainly restricted to sawdust incubated in/on abandoned arable soil. The use of bacterial colony forming units as indicators for bacteria biomass development may be questioned as many bacteria are not cultivable. However, PCRamplification of $16 \mathrm{~S}$ rDNA fragments of bacteria confirmed that bacteria were present in very low numbers in all treatments except sawdust in/on abandoned arable soil.

Acknowledgements The study was funded by TRIAS-SKB. This is publication number 4164 of the NIOO-KNAW Netherlands Institute of Ecology.

\section{References}

Agren GI, Bosatta E, Magill AH (2001) Combining theory and experiment to understand effects of inorganic nitrogen on litter decomposition. Oecologia 128:94-98

Bååth E (2001) Estimation of fungal growth rates in soil using $\mathrm{C}$-14-acetate incorporation into ergosterol. Soil Biol Biochem 33:2011-2018

Berg MP, Kniese JP, Zoomer R, Verhoef HA (1998) Long-term decomposition of successive organic strata in a nitrogen saturated Scots pine forest soil. For Ecol Manage 107:159-172

Blagodatskiy SA, Larionova AA, Yevdokimov IV (1993) Effect of mineral nitrogen on the respiration rate and growth efficiency of soil-microorganisms. Eurasian Soil Sci 25:85-95

Boddy L, Watkinson SC (1995) Wood decomposition, higher fungi, and their role in nutrient redistribution. Can J BotRevue Canadienne De Botanique 73:S1377-S1383

Bourbonnais R, Paice MG (1990) Oxidation of nonphenolic substrates - an expanded role for laccase in lignin biodegradation. Febs Letters 267:99-102

Carreiro MM, Sinsabaugh RL, Repert DA, Parkhurst DF (2000) Microbial enzyme shifts explain litter decay responses to simulated nitrogen deposition. Ecology 81:2359-2365

Daniel G (2003) Microview of wood under degradation by bacteria and fungi. In: Goodell B, Nicholas DD, Schultz TP (eds) Wood deterioration and preservation. Advances in our changing world. American Chemical Society, Washington, DC, pp 34-72

Daniel G, Volc J, Kubatova E (1994) Pyranose oxidase, a major source of $\mathrm{H}_{2} \mathrm{O}_{2}$ during wood degradation by Phanerochaete-Chrysosporium, Trametes-Versicolor, and Oudemansiella-Mucida. Appl Environ Microbiol 60:2524-2532

De Boer W, Verheggen P, Gunnewiek P, Kowalchuk GA, Van Veen JA (2003) Microbial community composition affects soil fungistasis. Appl Environ Micro 69:835-844

De Boer W, Folman LB, Summerbell RC, Boddy L (2005) Living in a fungal world: impact of fungi on soil bacterial niche development. FEMS Microbiol Rev 29:795-811

De Ridder-Duine AS, Kowalchuk GA, Klein Gunnewiek P, Smant W, Van Veen JA, De Boer W (2005) Rhizosphere bacterial community composition in natural stands of Carex arenaria (sand sedge) is determined by bulk soil community composition. Soil Biol Biochem 37:349-357

De Ridder-Duine AS, Smant W, Van der Wal A, Van Veen JA, De Boer W (2006) Evaluation of a simple, non-alkaline extraction protocol to quantify soil ergosterol. Pedobiologica 50:293-300

Eikenes M, Fongen M, Roed L, Stenstrøm Y (2005) Determination of chitosan in wood and water samples by acidic hydrolysis and liquid chromatography with online fluorescence derivatization. Carbohyd Polym 61:29-38

Eiland F, Klamer M, Lind AM, Leth M, Baath E (2001) Influence of initial $\mathrm{C} / \mathrm{N}$ ratio on chemical and microbial composition during long term composting of straw. Microbial Ecology 41:272-280

Fog K (1988) The effect of added nitrogen on the rate of decomposition of organic-matter. Biol Rev Camb Philos Soc 63:433-462

Frey SD, Elliott ET, Paustian K, Peterson GA (2000) Fungal translocation as a mechanism for soil nitrogen inputs to surface residue decomposition in a no-tillage agroecosystem. Soil Biol Biochem 32:689-698

Gong P, Guan X, Witter E (2001) A rapid method to extract ergosterol from soil by physical disruption. Appl Soil Ecol 17:285-289

Greaves H (1972) Influence of a mixed microbial population on Basidiomycete decay. Mater Org 7:11-25

Griffin DM (1985) A comparison of the roles of bacteria and fungi. In: Leadbetter ER, Poindexter JS (eds) Bacteria in nature. Plenum, New York, pp 221-255

Griffith GS, Bardgett RD (2000) Influence of resource unit distribution and quality on the activity of soil fungi in a particulate medium. New Phytol 148:143-151

Hobbie SE, Vitousek PM (2000) Nutrient limitation of decomposition in Hawaiian forests. Ecology 81:18671877

Holland EA, Coleman DC (1987) Litter placement effects on microbial and organic matter dynamics in an agroecosystem. Ecology 68:425-433

Jalal MAF, Read DJ (1983) The organic acid composition of Calluna heathland soil with special reference to phyto- 
and fungitoxicity I. isolation and identification of organic acids. Plant Soil 70:257-272

Johnson AR (1971) Improved method of hexosamine determination. Anal Biochem 44:628-635

Klein DA, Paschke MW (2004) Filamentous fungi: the indeterminate lifestyle and microbial ecology. Microb Ecol 47:224-235

Leonowicz A, Matuszewska A, Luterek J, Ziegenhagen D, Wojtas-Wasilewska M, Cho NS, Hofrichter M, Rogalski J (1999) Biodegradation of lignin by white rot fungi. Fungal Genet Biol 27:175-185

Moorhead DL, Sinsabaugh RL (2006) A theoretical model of litter decay and microbial interaction. Ecol Monogr 76:151-174

Mulder C, Van Wijnen HJ, Van Wezel AP (2005) Numerical abundance and biodiversity of below-ground taxocenes along a $\mathrm{pH}$ gradient across the Netherlands. J Biogeogr 32:1775-1790

Nicholas DD, Crawford D (2003) Concepts in the development of new accelerated test methods for wood decay. In: Goodell B, Nicholas DD, Schultz TP (eds) Wood deterioration and preservation. Advances in our changing world. American Chemical Society, Washington, DC, pp 288-312

Osono T, Hirose D, Fujimaki R (2006) Fungal colonization as affected by litter depth and decomposition stage of needle litter. Soil Biol Biochem 38:2743-2752

Prescott CE (1995) Does nitrogen availability control rates of litter decomposition in forests. Plant Soil 169:83-88

Romani AM, Fischer H, Mille-Lindblom C, Tranvik LJ (2006) Interactions of bacteria and fungi on decomposing litter: differential extracellular enzyme activities. Ecology $87: 2559-2569$
Scheu S, Schauermann J (1994) Decomposition of roots and twigs - effects of wood type (beech and ash) diameter, site of exposure and macrofauna exclusion. Plant Soil 163:1324

Schmidt O (2006) Wood and tree fungi. Biology, damage, protection, and use. Springer, Heidelberg

Shah V, Nerud F (2002) Lignin degrading system of white-rot fungi and its exploitation for dye decolorization. Can J Microbiol 48:857-870

Sjöberg G, Nilsson SI, Persson T, Karlsson P (2004) Degradation of hemi-cellulose, cellulose and lignin in decomposing spruce needle litter in relation to N. Soil Biol Biochem 36:1761-1768

Terziev N, Nilsson T (1999) Effect of soluble nutrient content in wood on its susceptibility to soft rot and bacterial attack in ground test. Holzforschung 53:575-579

Thiet RK, Frey SD, Six J (2006) Do growth yield efficiencies differ between soil microbial communities differing in fungal: bacterial ratios? Reality check and methodological issues. Soil Biol Biochem 38:837-844

Van der Wal A, Van Veen JA, Pijl AS, Summerbell RC, De Boer W (2006a) Constraints on development of fungal and decomposition processes during restoration of arable sandy soils. Soil Biol Biochem 38:2890-2902

Van der Wal A, Van Veen JA, Smant W, Boschker HTS, Bloem J, Kardol P, Van der Putten WH, De Boer W (2006b) Fungal biomass development in a chronosequence of land abandonment. Soil Biol Biochem 38:51-60

Waldrop MP, Zak DR, Sinsabaugh RL (2004) Microbial community response to nitrogen deposition in northern forest ecosystems. Soil Biol Biochem 36:1443-1451

Weete JD (1989) Structure and function of sterols in fungi. Adv Lipid Res 23:115-167 